\title{
Jarimatika Implementation in Early Childhood
}

\author{
Ratu Yustika Rini* \\ Early Chilhood Education, School of Postgraduates Studies \\ Universitas Pendidikan Indonesia \\ Bandung, Indonesia \\ *ratuyustika21@upi.edu
}

\author{
Sri Margorini \\ kindergarten teacher \\ Serang, Indonesia \\ srimargorini@gmail.com
}

\begin{abstract}
Jarimatika is often considered unable to be used in early childhood education because many teachers think that it is too early to be introduced. This article tries to analyze the implementation of Jarimatika in early childhood. The research method used is qualitative with a focus on a case study. Data were collected through observations at the Early Childhood Education Institute in Serang, Indonesia, who have used fingers as learning media in introducing initial arithmetic and conducting interviews with the principal, two class teachers, and four students' parents. After the data have been collected, they were analyzed using grounded theory which includes initial coding and focused coding. The post-developmentalist view is used as a theoretical framework. The results of the analysis of survey data and interviews revealed that two class teachers showed a positive impact on children's ability to count quickly. From the conclusions above, recommendations are given to early childhood institutions to better study the application of the Jarimatika method, as well as the readiness of the teacher in teaching Jarimatika to all children with their uniqueness. Thus, further research needs to conduct research on children who have special needs so that every individual is accommodated.
\end{abstract}

Keywords: Jarimatika, initial calculation, PAUD

\section{INTRODUCTION}

Jarimatika is one of the learning innovations in introducing early counting. Jarimatika is more commonly known among elementary schools with multiplication and fast counting which raises the perception that Jarimatika is still very early when applied to early childhood education. This perception makes researchers interested in analyzing the implementation of Jarimatika in early childhood.

My previous understanding of early childhood that always looked at the development of children with the practices of developmentalism that developed in early childhood education in Indonesia. Early childhood learning through play has encouraged the development of based approaches playing with a curriculum born in a European country [1]. The above was adopted by Indonesia by making several standards and curriculum containing births in 2045 in Indonesia [2]. This makes Indonesia increasingly dependent on the concepts that roam around in development so as to make the lack of information on learning that should be adjusted to the development of Indonesian children.
Jarimatika is one of the learning innovations in introducing early counting [3]. Jarimatika was developed by Septi Peni Wulandari who was anxious to see difficulties in using the Septi Peni Wulandari finger which was a housewife who came from Indonesia [4]. Jarimatika is one of the innovations made with the background of Indonesian children. This makes the developmentalism paradigm which considers the development of global nort children a little broken.

In addition, Wulandani explained the influence of Jarimatika techniques on the power of thought and psychology. Because it is given in a fun way, the limbic system in the child's brain will always be open, making it easier for children to accept new material. Familiarize children develop the right and left brain, both motorically and functionally [5]. Does not burden the brain's memory, so the child considers it easy, and this is the first step to build self-confidence to further master early mathematics.

Mathematics is a branch of science that is very important for any country. The rise and fall of a nation today depends on progress in the field of mathematics. Function mathematics can become Indonesia's endurance in the 21 st century [6]. The importance of mathematics for the progress of the nation requires students and students to deepen their knowledge of arithmetic and be able to apply it in everyday life. Anxiety makes the researcher understand that the importance of understanding early counting is given to early childhood by using appropriate methods in accordance with the characteristics of children.

Several research results have proven that the Jarimatika method can improve the ability of children's number concepts in kindergarten [7], the application of the Jarimatika method will run well if it is supported by the teacher's understanding and creativity in presenting a good and interesting Jarimatika method so that it can improve the understanding of initial counting in early childhood [8].

Although there have been studies of early counting arithmetic in early childhood through fingerprints, similar studies in the city of attack and using analytical techniques are still considered less specific in analyzing using the postdevelopmentalism perspective. Therefore, researchers are interested in further researching how to be perceived in the perspective of post-developmentalism and how the process of applying Jarimatics in early childhood. The subject in this 
research is the only kindergarten that applies Jarimatika in the city of attack. Ethical issues used in this study include asking permission for research, the confidentiality of informal identity and the relationship between the power of researchers and informants. The post-developmentalist view is used as a theoretical framework.

\section{METHODS}

The subject of this study was the principal, teachers and parents of the research students took the object of research in a kindergarten who had applied the Jarimatic technique so that the samples were taken using a purposive sample. This research was conducted for two months with observations for 4 weeks and semi-structured interviews for 2 weeks. This research uses a case study approach which is one of the designs in qualitative research that can further study the object of research through real life exploration through detailed data collection [9].

The problem that will be discussed in this study is the teacher's belief in readiness in the application of Jarimatika is a problem that underlies researchers in this study. Teachers 'beliefs about teaching have been studied from various perspectives, including how teachers' beliefs affect the interpretation of actual classroom practices regarding what they have learned from training and professional development [10] and their efforts and levels of resistance to new practices and reforms [11]. Feldon [12] emphasized the importance of analyzing teacher beliefs, arguing that "beliefs are the heart of teaching" and teacher beliefs are not only hypothetical understandings but also guide their behavior and decisions in class. In addition, researchers wanted to find out why this institution was able to apply initial numeracy learning using Jarimatika techniques.

\section{RESULTS AND DiSCUSSION}

The results of this study indicate that the application of Jarimatika in early childhood has not been fully able to touch all children. Because in its application the teacher treats all children equally so that the ability of each child is equal in value by the teacher regardless of the background of the readiness of the child and the child's family. So the need for understanding concepts that can indeed be fair to all children without having to generalize all the abilities of children, innovation is needed in providing stimulation of child development that is tailored to the interests of children and the child's condition. Jarimatika can be introduced by sharpening it in accordance with activities that everyday children encounter at home are generally fun, learning concretely using fingers and not forcing children to use Jarimatika in the introduction of arithmetic at first.

Meet this shows that in every institution that wants to apply a new concept must consider many things ranging from school readiness to the curriculum that is relevant to the stages of children's learning readiness. So that the application of concepts in learning methods that are expected to be the hallmark of an institution but instead neglect the stages of child development.

\section{A. Results}

The post-developmentalism view of teacher beliefs obtained from surveys and interviews with school principals, teachers and parents about the application of Jarimatika in early childhood shows that principals and teachers in this study understand and agree with the importance of introducing early counting in PAUD, but in interviews conducted by their teacher are still struggling to understand the concept of Jarimatika. Apart from the commitment of the principal and teachers to apply the introduction of initial arithmetic through the fingers technique, teachers often refute this idea in applying it to all children with the same actions, because understanding related to all children has a different appeal so the teacher in applying the fingerprinting technique is still not pay attention to that. Teachers are still eager to work on similarities and as a result, children only understand symbols without understanding concepts. As evidenced in the results of observations, the teachers force a child who comes from a background of mental readiness who is not ready to use the same fingers as people from a background of being mentally prepared. As we have explained in the findings, teachers seem to emphasize the idea of equality over equality.

This finding also shows that the teacher's readiness in applying the initial arithmetic using the Jarimatic technique has not yet found the right concept to apply it. Due to include fingerprinting techniques in every learning that demands relevant to the government curriculum and school curriculum. This is indeed a classic problem everywhere, teachers "face pressure from mandated curricula, inflexible daily schedules, and test preparations imposed" [13]. Therefore, a professionalism framework needs to be redefined. Should provide more room for teachers to improve their teaching rather than focus on documents. Providing more room for teachers to explore in teaching will enable them to explore a variety of topics, and, perhaps, this can make them better understand about counting quickly using fingers.

\section{B. Discussions}

The results of this study indicate that the application of jarimatika in early childhood has not been fully able to touch all children. Because in its application the teacher treats all children equally so that the ability of each child is equal in value by teacher regardless of the background of the readiness of the child and the child's family. So, the need for understanding concepts that can indeed be fair to all children without having to generalize all the abilities of children, innovation is needed in providing stimulation of child development that is tailored to the interests of children and the child's condition. Jarimatika can be introduced by sharpening it in accordance with activities that everyday children encounter at home are generally fun, learning concretely using fingers and not forcing children to use jarimatika in the introduction of arithmetic at first. 


\section{REFERENCES}

Meet this shows that in every institution that wants to apply a new concept must consider many things ranging from school readiness to the curriculum that is relevant to the stages of children's learning readiness. So that the application of concepts in learning methods that are expected to be the hallmark of an institution but instead neglect the stages of child development.

\section{CONCLUSION}

This article finds gaps arising from the lack of coordination between schools and parents so that the achievement of targets in the implementation of Jarimatics in early childhood is not optimal because there is no synchronization of the understanding that the teacher builds in beginning counting with the understanding built by parents in early counting, but the results The observations made indicate that children's understanding related to initial counting using fingerprints makes the child alert in answering simple addition or subtraction questions.

This research contributes to kindergarten in the implementation of fingers in early childhood. The need for further programs can be in the form of parenting related to learning methods that will be implemented for children, so that there is a synchronization of learning between school and home.

\section{ACKNOWLEDGMENT}

I thanks the teacher for his willingness to teach me, Sri Margorini, S.Pd., M.Sc. for useful advice in writing this article, also for both my parents who have given me the opportunity to attend graduate school and to graduate school who have funded the authors in publishing this article.
[1] L. Brooker, M. Woodhead. The right to play. The Open University with the support of Bernard van Leer Foundation; 2013.

[2] Buku kerangka besar pembangunn PAUD Indonesia Periode 2011-2025 Dirjen PAUDNI, Non Formal, Kemendiknas tahun 2011

[3] T. Astuti, Metode Berhitung Lebih Cepat Jarimatika. Jakarta: Lingkra Media. 2013.

[4] S. Rumra, "berhitung dengan Jarimatika.

[5] S.P. Wulandani, Jarimatika Penambahan dan Pengurangan. Jakarta: Kawan Pustaka, 2011.

[6] Metode pengajaran, Roxana Moreno, Universitas New Mexico, Richard E. Mayer, Universitas California Santa Barbara

[7] L. Ariyanti, Lusi. Meningkatkan Kemampuan Konsep Bilangan Anak Melalui Metode Jarimatika di TK Muslimat NU Miftahul Jannah. 2013. Vol. 2, No 2, 37-39.

[8] M.L. Patintingan. "Penerapan Metode Jarimatika Di Tk Asoka" Makassar. Vol. 5, No. 2, 2012.

[9] J.W. Creswell, Riset Pendidikan edisi kelima. Yogyakarta: Pustaka Pelajar. 2015.

[10] McMillan, H. James and S. Shumacher. Researc in Education a Conceptual Introduction 4th Ed. New York: Longman. 2010. 21(5): 4375. From:https://doi.org/10.3109/01421591003695303

[11] L. Breffni. Impact of curriculum training on state-funded prekindergarten teachers' knowledge, beliefs, and practices. Journal of Early Childhood Teacher Education. 2011. 32(2): 176-234. https://doi.org/10.1080/09588220802090253

[12] D.F. Feldon. Cognitive load and classroom teaching: the double edged sword of automaticity. Educational Psychologist. 2007. 42: 123-137. https://doi.org/ 10.1080/00461520701416173

[13] Sue, Vartuli. Selecting Curriculum Content that Stimulates Thought. Young Children. 2005. 60 (5): 76-86. https://doi.org/10.1007/s10643007-0209-0 